\title{
Astrocytes reassessment - an evolving concept part one: embryology, biology, morphology and reactivity
}

\author{
Alina Simona Şovrea* and Adina Bianca Boşca
}

\begin{abstract}
The goal of this review is to integrate - in its two parts - the considerable amount of information that has accumulated during these recent years over the morphology, biology and functions of astrocytes - first part - and to illustrate the active role of these cells in pathophysiological processes implicated in various psychiatric and neurologic disorders - second part.
\end{abstract}

Keywords: Astrocytes, Reactive astrogliosis, Molecular mechanisms, Therapeutic targets

\section{Introduction}

Increasing research interest aroused by astrocytes over the past few years led to a dramatic evolution of the concept regarding their structure and function. Ubiquitously present in all regions of the central nervous system (CNS), astrocytes are specialized glial cells, providing structural and functional support for neurons.

Although considered for more than 100 years as a homogenous cell population, it is known today that glia encompasses various morphological entities that coexist; each of these populations are characterized by a particular molecular signature and specific functions related to their microenvironment. Moreover, dysfunctions of astrocytes might contribute to CNS pathological remodelling and disease [1].

\section{Review}

\section{Short history}

The concept of neuroglia, introduced by Rudolf Virchow in 1858, described a connective substance of the brain, represented most likely by "fibers and intercellular masses". Otto Deiters, a German scientist, was the first who, in the second half of the $19^{\text {th }}$ century, drew the astrocytes as stellate cells; later, Jacob Henle and Friedrich Merkel observed the network formed by the astrocytes processes within the grey matter [2]. Yet it was Camillo

\footnotetext{
* Correspondence: a_sovrea@yahoo.com

Discipline of Histology, Department of Morphological Sciences, Iuliu Hațieganu University of Medicine and Pharmacy, Cluj-Napoca, Romania
}

Golgi (1872) the first who detailed and described the morphology of glial cells by using the silver-chromate technique (a black staining reaction); he observed that some glial cells (known today as protoplasmic astrocytes) displayed endfeet on their processes, attached to the blood vessels. His theory postulated that there was a link between the morphology and function of astrocytes in the CNS; regarded as the "glue" of the brain, glial cells established an interconnection between vessels and parenchyma, therefore being responsible for metabolic exchanges. In 1893 Michael von Lenhossek contrived the term "astrocyte" that illustrated the morphology of these cells. The origin of this term arouse from a combination of the latin word for stars, astra, with the word for cell, cyte, thus a star-shaped cell [3]. Astrocytes were further classified into protoplasmic (found in the grey matter) and fibrous (within the white matter) [2-4].

At the beginning of the 20th century the morphological heterogeneity of the CNS glia was definitely set. However, only when Santiago Ramón y Cajal (1913) has developed the gold chloride-sublimate staining technique, the first specific stain for astrocytes, this diversity was acknowledged. Cajal is considered the promoter of the future stem properties of neuroglia since, using this method, he proved that astrocytes originate from radial glia and undergo cell division in the adult brain. Numerous functions of astrocytes (e.g. neuronal nutrition and metabolism, nervous tissue homeostasis, brain cytoarchitecture, glial scar formation) were further determined, 
relying on Cajal's histological research, rendering astrocytes essential brain "homeostatic cells" either in normal or pathologic conditions [5].

Yet, the gains regarding the functions of astrocytes were shadowed by the lack of adequate techniques that could have promoted them, versus neurons of which value was overstated by the neuronal doctrine [2].

\section{Phylogenetic evolution}

From the phylogenetical point of view, the organization of a centralized nervous system was marked by the appearance of astrocytes [5].

An interesting aspect is the constant augmentation the astrocytes/neurons ratio that parallelized the evolution of the brain (about 0.16 in nematodes to 0.33 in rodents, and reaching up to 1.65 astrocytes per neuron in the human cortex) [6]. It is considered that, in the human brain, to each neuron correspond 10 glial cells. In smaller creatures' brain, the number of glial cells corresponding to a neuron is significantly reduced [7].

The primordial astrocytes performed a wide range of functions in the development of the nervous system. In nematodes, the astrocytes are not only involved in neuronal development, but also enable the sensory functions [5]. Moreover, the astrocytes' performances improve with the evolutionary stages. For example, in arthropods glial cells fulfill an additional role, organizing the neurons in functional definite nervous centers [5]. In crustaceans, insects and cephalopods, even in some vertebrates (sharks), the astrocytes form the blood-brain barrier (BBB) or the hemolymph-brain barrier (HBB) isolating the nervous tissue from the rest of the body [5]. Primordial astrocytes also envelop the axons therefore being the predecessors of the myelin forming cells; the astroglial sheath of the axons improves the propagation of the action potential [5]. In higher vertebrates, astrocytes' role in maintaining the BBB function is completed by the endothelial cells. Besides, in this stage of evolution, astrocytes specialize for the defensive function [5]. In humans, astrocytes achieve their greatest morphologic and functional complexity. For example, neocortex humans astrocytes compared to those of rodents, are 2.5 times larger, their processes are 10 times more numerous and they display particular histological features; the action potential velocity is also 4 times higher [7].

\section{Stem cells and astrocytes differentiation}

Initially astrocytes were identified due to their star-shaped morphology and presence of the glial fibrils. Nowadays these features are almost outdated.

The diversity of astrocytes is justified by two main factors: the heterogeneity of glial precursors and the various pathways of specific differentiation, both being influenced by the extracellular environment. Recent in vitro studies reported that growth factors levels activate in astrocytes the gene expression and regulate the transcription factors so that the subsets of progenitors are spontaneously engaged in different pathways of development [8]. During their differentiation, between the glial precursors and the microenvironment there is a mutual influence: cells secrete various soluble factors, and, on the other hand, the extracellular matrix (ECM) molecules (e.g. lectican and tenascins family) have the ability to stimulate or to inhibit cells proliferation, maturation and migration $[9,10]$. Thus, in his study, Haas C. et al. in 2012, observed that by treating GRP in vitro with specific culture media, different astrocytic phenotypes were obtained (e.g. A2B5-/GFAP+ with a flat morphology fibroblast-like when treated with fetal bovine serum and A2B5+/GFAP+ star-shaped astrocytes when treated with both basic fibroblast growth factor (bFGF) and ciliary neurotrophic factor (CNTF) [8].

For example, if we consider a multipotent stem cell as a source of astrocytes, but initially, this cell has produced neuronal precursors, the turn towards glial differentiation implies a multi-step process. At first, a specific receptor on the surface of the multipotent stem cell modifies its structure to gain affinity for growth factors such as: fibroblast growth factor (FGF) and epidermal growth factor (EGF); then, the resulting glial precursor is subjected to the action of signalling molecules (e.g. CNTF, bone morphogenetic proteins (BMF) and EGF) that will control and continue its maturation $[9,10]$.

However, further research is needed in order to identify the heterogeneous subpopulations of astrocytes progenitors and accurately characterise them by new antigenic markers, physiological properties or molecular profiles [1].

At present, three distinct pools of glial progenitors have been described in the germinal niches of the cerebral cortex: a) radial cells of the ventricular zone b) postnatal glial progenitor cells of the subventricular zone and c) glial-restricted precursors (GRP) - also found in the embryonic spinal cord (see Table 1) [3,8].

The grey matter protoplasmic astrocytes are mostly generated by embryonic radial glia but also from the intermediate progenitors arisen from neonatal subventricular zones. Due to their different origin, the two populations of astrocytes will display different patterns of gene expression, which will enable potential different functions. The white matter fibrous astrocytes originate, instead, mainly from neonatal subventricular zone progenitors [1].

\section{Astrocytes-like neural progenitors}

An unexpected finding in the astrocyte research is the identification in the adult neurogenic zones - subventricular zone (SVZ) and subgranular zone (SGZ) - of a subtype of astrocytes considered to be the local stem cells. Regarded as mature astrocytes due to the expression of 
Table 1 Ontogenetic astrocyte progenitor pools

\begin{tabular}{|c|c|c|c|c|}
\hline & Radial glia & Postnatal glial progenitor cells & Glial restricted prec & arsors \\
\hline \multirow[t]{3}{*}{ Origin } & \multirow[t]{3}{*}{ Neuroepithelial cells [1] } & - Radial glia [11,12] & \multicolumn{2}{|c|}{ Neuroepithelial cells skipping the radial glia stage $[13,14]$} \\
\hline & & • Dlx2 (distal-less homeobox 2) [3] & & \\
\hline & & - Local glial progenitors [1] & & \\
\hline \multirow[t]{3}{*}{ Location } & Ventricular zone [1] & - Subventricular zone & $\begin{array}{l}\text { - Embryonic spinal } \\
\text { cord [8] }\end{array}$ & - Optic nerve [8] \\
\hline & & - Dorso-lateral subventricular zone & & \\
\hline & & • Marginal zone $[1,11,12]$ & & \\
\hline \multirow[t]{2}{*}{ Characteristics } & Multipotential cells $[11,12]$ & - Multipotential cells & Tripotential cells [8] & - Bipotential cells O-2A, O-2A/OPC $[8,15]$ \\
\hline & & - Bipotential cells [3] & & \\
\hline \multirow[t]{3}{*}{ Roles } & $\begin{array}{l}\text { - Progenitors for neurons } \\
\text { and glial cells }\end{array}$ & $\begin{array}{l}\text { - Intermediate progenitors for } \\
\text { astrocytes and oligodendrocytes [3] }\end{array}$ & $\begin{array}{l}\text { - Promote } \\
\text { neuroprotection }\end{array}$ & $\begin{array}{l}\text { - Tumor genesis (oligoastrocytomas, } \\
\text { multiform glioblastomas) [15] }\end{array}$ \\
\hline & $\begin{array}{l}\text { - Guidance of neuronal } \\
\text { migration }[11,12]\end{array}$ & & $\begin{array}{l}\text { - Reduction of glial } \\
\text { scar }\end{array}$ & \\
\hline & & & $\begin{array}{l}\text { - Formation and } \\
\text { axonal growth [8] }\end{array}$ & \\
\hline \multirow[t]{3}{*}{$\begin{array}{l}\text { Type of resulting } \\
\text { astrocytes }\end{array}$} & $\begin{array}{l}\text { - Star shaped specialised } \\
\text { cortical astrocytes }\end{array}$ & - Cortical astrocytes & - Self-renewal & $\begin{array}{l}\text { - Astrocytes type } 2 \text { and oligodendrocytes } \\
\text { (in vitro) }\end{array}$ \\
\hline & & - White matter astrocytes & $\begin{array}{l}\text { - Astrocytes types 1, } \\
2 \text { and }\end{array}$ & \\
\hline & $\begin{array}{l}\text { - Bergmann glia in the } \\
\text { cerebellum }[3,16]\end{array}$ & - Oligodendrocytes [3] & $\begin{array}{l}\text { - Oligodendrocytes } \\
\text { [8] }\end{array}$ & - Oligodendrocytes (in vivo) $[8,15]$ \\
\hline
\end{tabular}

GFAP and glycogen granules, these cells unusually display features of both radial glia and neural progenitors (e.g. synaptic mediators' release) [1].

It was demonstrated that the specific pro-neural genes (e.g. neurogenin-2 and Mash1) enable these astrocytes to regain their stem cells properties being able to differentiate into neurons [1]. Additionally, the embryonic extracellular matrix molecules present in the neurogenic niche are capable to maintain these cells' "stemness" [1,17].

In the adult SVZ and SGZ, two distinct population of neural progenitors (multipotent neural stem cells) express GFAP [1,18-20]. The SVZ progenitors and give rise to neuroblasts which migrate to the olfactory bulb (to become olfactory interneurons) [1,19-22]. GFAP-expressing cells found in the SVZ are also been referred to as astrocytes-like cells or B cells. From the histological point of view, these cells are irregular in shape, filling in the spaces between neighbouring cells; their cytoplasm is pale with few organelles (e.g. free ribosomes) but numerous intermediate filaments; the nuclei are also irregular due to the invaginations on their surface. There are significant differences between the two types of SVZ astrocytes. Type 1 (i.e. B1 cells) are larger, with euchromatic nuclei and are located in the proximity of the ependymal cells. Type 2 (i.e. B2 cells) are smaller, with hyperchromatic nuclei and are mostly adjacent to the striatal parenchyma. The SGZ neural progenitors generate newborn granular neurons [1].

Another type of stem cell which expresses GFAP can be found in the adult SVZ but it is not certain that these adult stem cells are, in fact, astrocytes. They have different molecular features, because they express nestin (an intermediate filament), that characterise only embryonic astrocytes, reactive astrocytes or neuroblasts and intermediate progenitors [1].

Considering the high plasticity of astrocytes, the GFAP expressing cells in the neurogenic niche can simultaneously behave as both astrocytic and neural stem cells [1].

\section{Astrocytic markers and stains}

Important advances in technologies to study the nervous tissue enabled the knowledge of astrocytes characteristics (see Table 2), Figures 1, 2 and 3. (All images presented in here, are microphotographs of human brain samples prelevated by autopsy in compliance with the Protocol elaborated by the Ethics Committee of "Iuliu Hatieganu" University of Medicine and Pharmacy Cluj-Napoca).

For example, the grey matter protoplasmic astrocytes, are generated from embryonic radial glia and, to a lesser extent, from intermediate progenitors migrating from the neonatal subventricular zones. These two pathways 
Table 2 Astrocytic markers and stains

Procedures
(H-E) [23]

\section{Characteristics}

Routine staining for basic morphology

Cytoplasm extracellular protein components

Mallory's (phosphotungstic acid - hematoxylin) stain [24]

Orange-acridine stain [24]

Metallic impregnations [23]

- Del Rio Hortega method

- Ramon y Cajal method (see Figures 1 and 2)

- Golgi stain

Electron microscopy [24]

Immunohistochemistry
Special stain

Special stain

- Special technique with ammonia silver carbonate

- Special technique with gold chloride

- Special technique with silver nitrate
Golden standard for the definition of astrocytes

- There are different clones of antiGFAP antibodie, characteristic to the different research

- Laboratories (e.g. GF2 DAKO clone; Astro 1) $[23,24]$
Cytoplasm intermediate GFAP

Cell body

Astrocyte processes (deep blue)

Cellular body

Nuclei

Cytoplasm processes

Cell processes (positive immunostaining reaction: brown spots)

\section{Observation}

- Astrocytes are difficult to identify (nuclei: small, pale, ovoidal, euchromatic and centrally situated, are mimicking those of small neurons; cytoplasm and cellular processes are undifferentiated from those of neighbouring neurons)

- The occasionally pericellular hallo (autolitic modification) impose a differential diagnosis with the oligodendrocytes [23]

- Reveals the astrocytic hyperplasia, without the modification of the cytoplasm aspects [24]

- Reveals the cellular characteristic starshaped aspect

- The abundant cytoplasm surrounding the nuclei differentiates the astrocytes from oligodendrocyte

- The fibrillar aspect of the cytoplasm is due to the material formed by the aggregation of GFAP intermediate filaments

- The vascular endfeet are easy to identify.

- Protoplasmic astrocytes, due to their proximity to the blood vessels, are able to contact the vessel directly by their cell body

- The perivascular hallo is considered to be an artefact [23].

- Cytoplasm pale, with lack of organelles

- The clear, perivascular spaces indicate excessive dilatation of astrocytic processes due to water imbibitions

- The ultrastructural resemblance between normal and well differentiated neoplastic astrocytes is one of the arguments against the use of this method for positive diagnosis of low grade glioma [24]

GFAP represents an integrator of the cellular space, but it is also implicated in complex cellular events, such as cytoskeleton reorganisation, myelination, cellular adhesion and several signalling pathways $[23,24]$.

- Fibrillary astrocytes contain a massive amount of GFAP in their cell bodies and processes unlike protoplasmic astrocyte.

- Protoplasmic astrocytes are much larger than their GFAP-defined profiles due to the presence of numerous fine processes that are GFAP-negative

- In astrocytomas, along with the enhancement of malignity, the intracellular quantity of GFAP is progressively reduced: therefore the evaluation of GFAP immunohistochemical staining will enable the immunophenotypic characterisation of the investigated glial tumors and the confirmation of histopathological diagnosis 
S100B (belongs to the $\mathrm{S} 100$ family of EF-band calcium binding proteins $[1,31]$ )

Other astrocytic markers

- GLT-1 (the glutamate transporters GLAST) [6]

- Human EAAT2 (excitatory amino acids, 1 and 2 for human brain) [6]

- Glycogen granules [6]

- Gglutamine synthase (GS) [1,32-35]

Kir4.1 (inwardly rectifying $\mathrm{K}^{+}$ channels) $[1,36,37]$

- Aquaporin 4 channels $[1,38]$

- AldhL1 (aldehyde dehydrogenase 1 family, member L1) $[1,39]$.

Battery of tests [40]. GFAPdriven GFP (green fluorescent protein)

expressionGFAPprotein

expression, $\mathrm{S} 100 \mathrm{~B}$

immunostaining

- GFAP expression glutamate response [41]

Dye-filling techniques $[6,42]$ (e.g. sharp electrode, patch clamp recordings, single cell electroporation)
There are different clones of anti S100 antibodies,

characteristic to the different research laboratories

(e.g. MAB079, CBL410.)

GS- enzyme that catalyzes the conversion of ammonia and glutamate to glutamine

Cell processes

Genome

Combinatorial approach

Special techniques that identify cells recorded in situ after filling them with a dye present in a micro-electrode

It is suplemented by use of presumed astrocyte-

Specific promoters to drive synthesis of fluorescent proteins

Cytoplasm

Cytoplasm

Cell body

Cell processes
- Not all the cells in the CNS that express GFAP are astrocytes (e.g: astrocyte-like cells from the SVZ-derived from radial glia, ependymal cells) $[1,25,26]$

- GFAP has also been located in rat kidney glomeruli and peritubular fibroblasts $[1,27]$, Leydig cells of the testis $[1,28]$, skin keratinocytes $[1,29]$, osteocytes of bones, chondrocytes of epiglottis, bronchus [1,30], and stellate-shaped cells of the pancreas and liver [1]

- Expressed by a subtype of mature astrocytes that ensheath blood vessels and by NG2-expressing astrocytes $[1,31]$

GLT-1 is expressed by all astrocytes and provide punctuate staining [6]

GS is expressed also by oligodendrocytes [1,32-35]

Kir4.1 are only expressed by a subset of astrocytes [37]

- Aquaporin 4 channels is localized in some parts of the astrocytic processes rendering identification of the whole cell difficult to interpret [38]

- All astrocytes

- Nine different classes of astrocytes has been identified, that included Bergmann glia, ependymal glia, fibrous astrocytes, marginal glia, perivascular glia, protoplasmic astrocytes, radial glia, tanycytes and velate glia $[3,40]$

- Define the phenotype of an astrocyte population as $\left(\mathrm{GFAP}^{+} / \mathrm{NG2}^{-} ; \mathrm{T}^{+} / \mathrm{R}^{-}\right)$which is distinct from NG2-glia (GFAP ${ }^{-} / \mathrm{NG}^{+} \mathrm{T}^{-}$/ $\mathrm{R}^{+}$) [41]

- This technique has the advantage that the cells to be studied can be preselected in living tissue [6,42]

- However, proteins and promoter activation are subjects to change. Hence one can have a GFAP(-) cell that one should call an astrocyte because it has these other properties $[6,42]$

- Using these procedures the domain organisation of astrocytes has been demonstrated along with the fusiform morphology of astrocyte nucleus, both playing a possible role in pathology $[3,43,44]$

Cell body 
Table 2 Astrocytic markers and stains (Continued)

\begin{tabular}{lll}
\hline Transgenic techniques & Visualize fluorescent & Cell processes \\
(use transgenic mice) $[1]$ & astrocytes & - Enhanced GFP under the human GFAP \\
& promoter (hGFAP-GFP mice) \\
& - GLT-1-GFP \\
& - BLBP-dsRed2 \\
\hline
\end{tabular}

of development will generate astrocytes with different patterns of gene expression and possibly different functions.

On the other hand, the white matter fibrous astrocytes are predominantly generated from neonatal subventricular zone progenitors [1].

Yet, it is important to recognize that subsets of progenitors will spontaneously differentiate in culture, as the intrinsic program of the cells modulates the process of cell division and differentiation together with culture conditions. Nevertheless, treatment of GRP cultures with fetal bovine serum (FBS) resulted in the production of A2B5-/GFAP + astrocytes with a fibroblastlike flat morphology, whereas exposure to basic fibroblast growth factor (bFGF) together with ciliary neurotrophic factor (CNTF) produced mostly process-bearing A2B5+/GFAP + astrocytes. Further research is needed to elucidate the identity of the different classes of intermediate progenitors or to obtain a clear antigenic signature of the lineage [8].

The development of astrocytes from a multipotent stem cell that prior to this has produced neuronal precursor cells, implies a specific differentiation via a multistep process. The switch toward the glial differentiation is

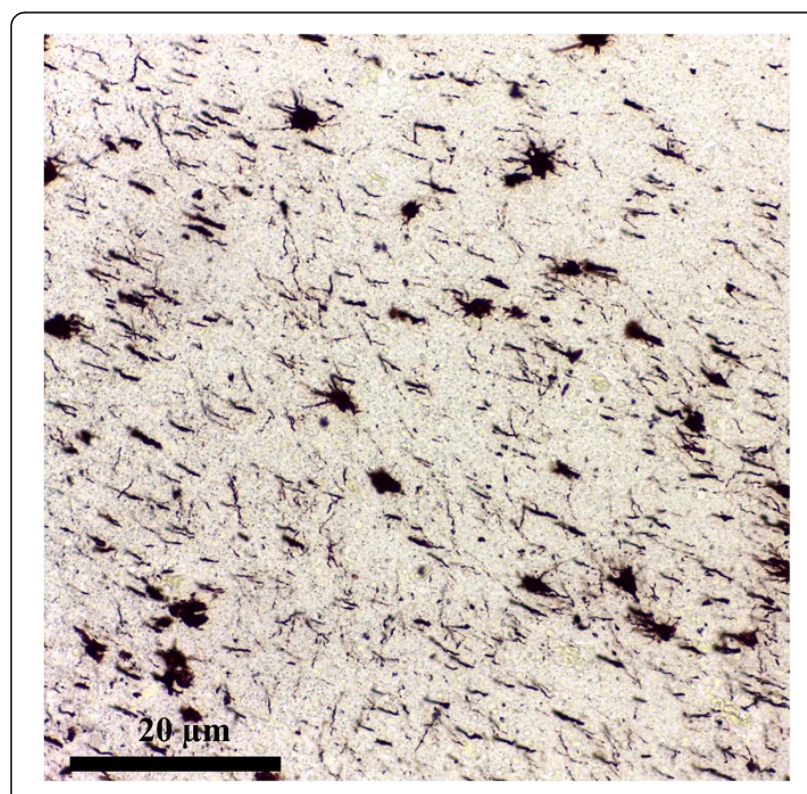

Figure 1 Astrocytes overview. Metalic impregnation Ramon Y Cajal Ob. 20x. Human brain (personal collection). regulated by a change in receptor composition on the cell surface and responsiveness to fibroblast growth factor (FGF) and epidermal growth factor (EGF); futhermore, signaling molecules like CNTF, bone morphogenetic proteins (BMF), and EGF will continue to drive the glial precursor cell into the astroglial direction. However, the early astrocytes will interact with their microenvironment not only by releasing and responding to diverse soluble factors, but also expressing a wide range of extracellular matrix (ECM) molecules, as proteoglycans (lectican family) and tenascins. Lately it is considered that these ECM molecules have the ability to participate in glial development (e.g. the matrix protein Tenascin $\mathrm{C}$ (Tnc), proved to be an important regulator of astrocyte precursor cell proliferation, maturation and migration during spinal cord development) and those expressed by reactive astrocytes under pathophysiological conditions, are known to act mostly in an inhibitory fashion $[9,10]$.

\section{Astrocytes as a source of stem cells}

The most recent and exciting finding in the astrocyte field, which challenges the traditional definition of astrocyte itself, is the discovery that there is a subclass of mature

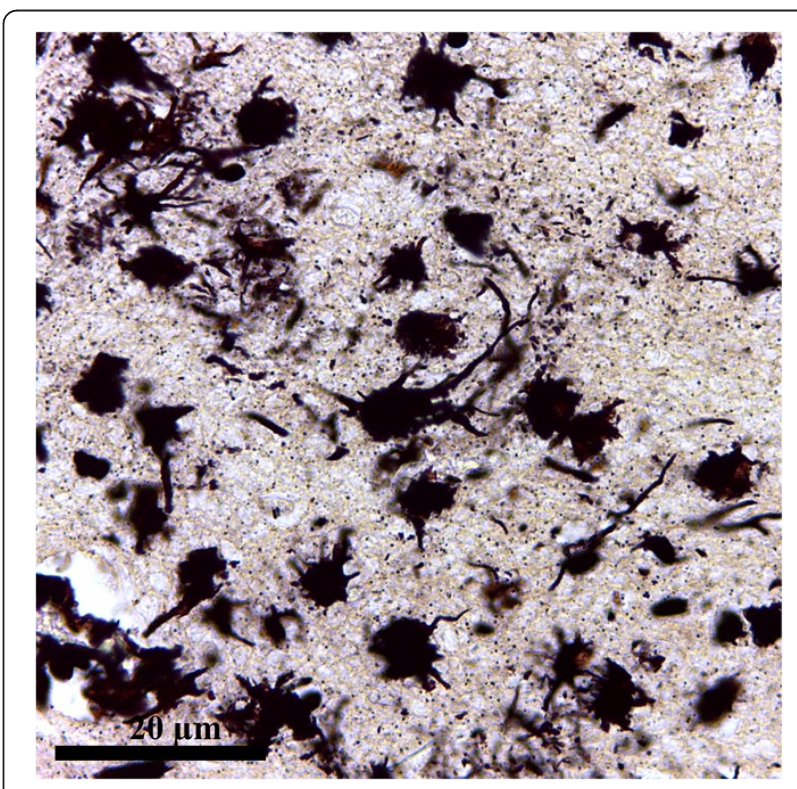

Figure 2 Astrocytes overview. Metalic impregnation Ramon Y Cajal Ob. 40x. Human brain (personal collection). 


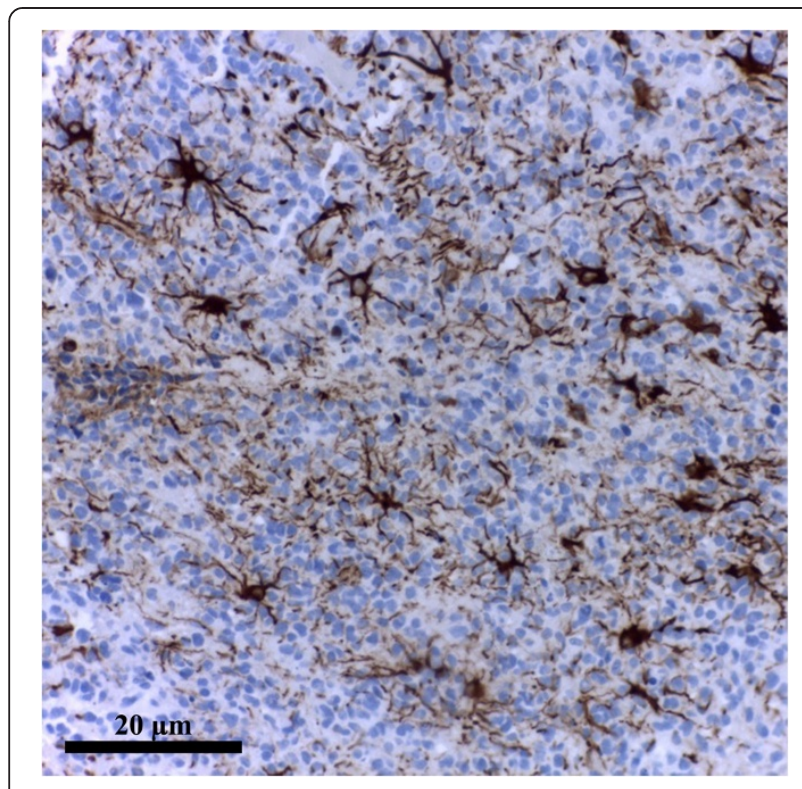

Figure 3 Astrocytes overview. GFAP Clone GF2 DAKO. Human brain. Ob. 20x. (personal collection).

astrocytes which represent the stem cells in the adult neurogenic zones. The GFAP-expressing stem cells have characteristics of embryonic radial glia and mature astrocytes, but display subtle differences and retain properties of neural progenitors. These stem cells act in concert with resident astrocytes to contribute to cell genesis and maintaining the neurogenic environment, the niche. Perhaps these cells are retained in a transitional stage between radial glia and astrocytes, due to the persistence of embryonic extracellular matrix molecules. This permissive environment in the neurogenic niche allows the retention of intrinsic genetic programs to maintain "stemness" $[1,17]$. It was shown that, the proneural genes neurogenin-2 and Mash1 possess the ability to reprogram these astrocytes to stem cells that can generate neurons [1].

In the adult subventricular zone (SVZ) and subgranular zone (SGZ), two distinct population of neural progenitors (multipotent neural stem cells) express GFAP [1,18-20] and give rise to neuroblasts that either migrate to the olfactory bulb (to become olfactory interneurons) $[1,19,21,22]$ or generate newborn granule neurons. GFAPexpressing cells of the SVZ have been termed SVZ astrocytes, astrocyte-like cells or B cells. The histology of these cells comprises irregular contours that filled the spaces between neighbouring cells, irregular nuclei with invaginations, and light cytoplasm with few free ribosomes. They also expressed abundant intermediate filaments. Differences were found between the two types of astrocyte-like cells. Type B1 cells are larger than type B2 cells and possess euchromatic nuclei; they are adjacent to ependymal cells. Type B2 cells are smaller with hyperchromatic nuclei and are mostly located at the interface with the striatal parenchyma [1].

Another type of stem cell which expresses GFAP can be found in the adult SVZ but it is questionable whether these adult stem cells really belong to the astrocyte family. They has different molecular features, because they express nestin (an intermediate filament), that characterise only embryonic astrocytes, reactive astrocytes or neuroblastes and intermediate progenitors [1].

In conclusion, there is much need for further studies to be conducted in an attempt of finding new antigenic markers, physiological properties or molecular profiles for a better definition of these varieties of stem cells and to answer to challenging question as the ability of every astrocyte to revert to stem cells given the right environment [1].

\section{Astrocytic markers and stains}

Many novel tools to study astrocytes were given by the technological advances over the past decades. From the early Golgi stains to immunostaining for glial fibrils, or the recent dye-filling techniques (e.g. sharp electrode, patch clamp recordings, single cell electroporation), and transgenic approaches to visualize fluorescent astrocytes, our understanding of astrocyte characteristics has dramatically evolved [1] (see Table 2), Figures 1, 2 and 3.

The morphological features and the close relationships with both neurons and capillaries are the most constant characteristics that can be used to define the astrocytic phenotype [3] (see Figure 4).

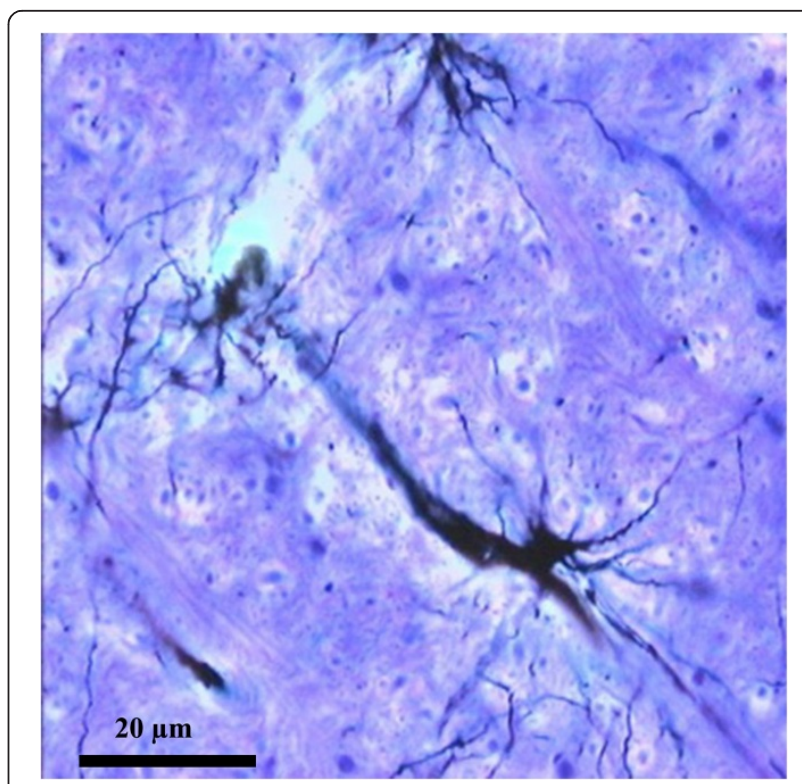

Figure 4 Protoplasmic astrocyte proximal to a blood vessel. Metallic impregnation Ramon Y Cajal. Ob. 20x. Human brain (personal collection). 
Table 3 Types of astrocytes

\begin{tabular}{|c|c|c|c|c|}
\hline Types of astrocytes & Location & Morphology & Functions & Particularities \\
\hline \multirow[t]{5}{*}{ Protoplasmic astrocytes } & \multirow{5}{*}{$\begin{array}{l}\text { Uniformly } \\
\text { distributed within } \\
\text { the grey matter [3] }\end{array}$} & \multirow{5}{*}{$\begin{array}{l}\text { Bushy appearance, with } \\
\text { numerous short, branched, } \\
\text { thick processes [50]. The } \\
\text { cell body is ovoid or } \\
\text { fusiform (see Figure 5) }\end{array}$} & - Form the blood-brain barrier & \multirow{2}{*}{$\begin{array}{l}\text { Their processes exhibit endfeet } \\
\text { enveloping the synapses and the } \\
\text { blood vessels [51]. The processes } \\
\text { express }\end{array}$} \\
\hline & & & - Regulate the blood flow & \\
\hline & & & - Neuronal metabolism & $\begin{array}{l}\text { - Receptors for neurotransmitters, } \\
\text { cytokines, growth factors }\end{array}$ \\
\hline & & & $\begin{array}{l}\text { - Implicated in the synapse } \\
\text { function }\end{array}$ & - Transporters \\
\hline & & & $\begin{array}{l}\text { - Fluid, ion, } \mathrm{pH} \text { and transmitter } \\
\text { homeostasis [45] }\end{array}$ & $\begin{array}{l}\text { - Ion channels [7]. In rodents, there } \\
\text { is minimal overlapping between } \\
\text { the processes of the } \\
\text { neighbouring astrocytes } \\
{[43,44,52-54] \text {. In humans, the }} \\
\text { superposition of the domains } \\
\text { occupied by the astrocytes } \\
\text { processes is augmented [3] }\end{array}$ \\
\hline Fibrous astrocytes & $\begin{array}{l}\text { Within the white } \\
\text { matter, oriented } \\
\text { longitudinally, along } \\
\text { the nervous fibers } \\
\text { bundles [1] }\end{array}$ & $\begin{array}{l}\text { Star-shaped cells. Posses } \\
\text { long, thin and straight } \\
\text { processes [45] } \\
\text { (see Figure 6) }\end{array}$ & & $\begin{array}{l}\text { Their endfeet processes envelop } \\
\text { the nodes of Ranvier and the } \\
\text { blood vessels [45] }\end{array}$ \\
\hline Interlaminar astrocytes & $\begin{array}{l}\text { In the molecular } 1 \text { st } \\
\text { layer of the cerebral } \\
\text { cortex, next to the } \\
\text { pial surface }\end{array}$ & $\begin{array}{l}\text { Spherical cell bodies and } \\
\text { processes }\end{array}$ & $\begin{array}{l}\text { Unknown Support the calcium } \\
\text { wave propagation in humans [3] }\end{array}$ & $\begin{array}{l}\text { Are found only in humans and } \\
\text { primates. Their processes are } \\
\text { included in the pial glial } \\
\text { membrane, creating a thick } \\
\text { network of GFAP fibers [46-49] }\end{array}$ \\
\hline $\begin{array}{l}\text { Varicose projection } \\
\text { astrocytes }\end{array}$ & $\begin{array}{l}\text { In the } 5 \text { th and the } \\
\text { 6th layers of the } \\
\text { cerebral cortex }\end{array}$ & $\begin{array}{l}\text { Exhibit } 1 \text { to } 5 \text { long } \\
\text { processes (up to } 1 \mathrm{~mm} \text { in } \\
\text { length), characterized by } \\
\text { evenly }(10 \mu \mathrm{m}) \text { spaced } \\
\text { varicosities }[3,46]\end{array}$ & Unknown & $\begin{array}{l}\text { Were identified only in humans } \\
\text { and chimpanzees. They are GFAP } \\
\text { cells }[3,46]\end{array}$ \\
\hline $\begin{array}{l}\text { Bergmann glia } \\
\text { (epithelial glial cells) }\end{array}$ & $\begin{array}{l}\text { In the Purkinje-cell } \\
\text { and the granular } \\
\text { layers of the } \\
\text { cerebellar cortex }\end{array}$ & $\begin{array}{l}\text { Posses long processes } \\
\text { extending towards the } \\
\text { molecular layer of the } \\
\text { cerebellar cortex, in a fan- } \\
\text { like arrangement, exhibiting } \\
\text { pial vascular endfeet [23] }\end{array}$ & $\begin{array}{l}\text { Implicated in synapse function: } \\
\text { capable to interfere with synaptic } \\
\text { transmission by communicating } \\
\text { with neurons via the extracellular } \\
\text { space, by modulating ion } \\
\text { concentrations or transmitter } \\
\text { levels in the synaptic cleft [23] }\end{array}$ & $\begin{array}{l}\text { Display receptors with distinct } \\
\text { biophysical and pharmacological } \\
\text { features allowing them to sense } \\
\text { the activity of synapses [23] }\end{array}$ \\
\hline Fananas cells & $\begin{array}{l}\text { In the molecular } \\
\text { layer of the } \\
\text { cerebellar cortex }\end{array}$ & $\begin{array}{l}\text { Posses several short side } \\
\text { processes with a } \\
\text { characteristic feather-like } \\
\text { arrangement [23] }\end{array}$ & & \\
\hline \multirow[t]{2}{*}{ Müller cells } & \multirow[t]{2}{*}{$\begin{array}{l}\text { In the } 6 \text { th layer of } \\
\text { the visual retina }\end{array}$} & & $\begin{array}{l}\text { Supportive cells: they form the } \\
\text { inner and the outer limiting } \\
\text { membranes }\end{array}$ & $\begin{array}{l}\text { The limiting membranes consist of } \\
\text { junctional complexes between the } \\
\text { cellular processes of the Müller } \\
\text { cells }\end{array}$ \\
\hline & & & $\begin{array}{l}\text { The outer membrane separates } \\
\text { the external segment of the } \\
\text { photoreceptor cells from the cell } \\
\text { bodies and the outer membrane } \\
\text { separates the retina from the } \\
\text { vitrous body [23] }\end{array}$ & $\begin{array}{l}\text { They have an intense metabolic } \\
\text { activity and contain microfilaments } \\
\text { and glycogen within their } \\
\text { cytoplasm [23] }\end{array}$ \\
\hline \multirow[t]{2}{*}{ Pituicytes } & \multirow[t]{2}{*}{$\begin{array}{l}\text { In the } \\
\text { neurohypophysis }\end{array}$} & \multirow{2}{*}{$\begin{array}{l}\text { Irregular in shape with } \\
\text { many cytoplasmic } \\
\text { processes extending in the } \\
\text { proximity of the capillaries } \\
\text { and surrounding the } \\
\text { Herring bodies [24] }\end{array}$} & & $\begin{array}{l}\text { Their cytoplasm contains lipid } \\
\text { droplets and pigment granules. }\end{array}$ \\
\hline & & & & $\begin{array}{l}\text { They are immunoreactive for GFAP, } \\
\text { vimentin and S100 protein [24] }\end{array}$ \\
\hline $\begin{array}{l}\text { Inerstitial epiphysial } \\
\text { cells }\end{array}$ & In the epiphysis & $\begin{array}{l}\text { Exhibit cytoplasmic } \\
\text { processes }\end{array}$ & & $\begin{array}{l}\text { Contain numerous filaments within } \\
\text { their processes [23] }\end{array}$ \\
\hline
\end{tabular}




\section{Types and morphology}

Two major classes of astrocytes were first described in the 19th century by using the Golgi staining, which revealed their distinct morphological pattern: the protoplasmic and fibrous astrocytes. Nowadays the classification of astrocytes into fibrous and protoplasmic is considered to be outdated [45]; their morphological diversity can be illustrated by specialised classes of astrocytes represented by: the cerebellar Bergmann and Fananas glia, the Müller glia of the retina, the pituicytes of the neurohypophysis and the interstitial cells of the epiphysis. Additionally, in humans and primates two novel subtypes of astrocytes have been described: interlaminar astrocytes and varicose projection astrocytes [3,4,46-49]. (see Table 3) Figures 5 and 6.

The above presented heterogeneity of astrocytes could arise from separate lineages, plasticity of mature cells (motility and reactivity after injuries), or association of both factors [3,54]. Methods of molecular biology, like time-lapse studies in slice culture, demonstrated the participation of astrocytes in synaptic remodelling, since the astrocytic processes are motile and enwrap active synapses $[3,55,56]$.

It is well-known that mature astrocytes can exhibit forms of plasticity: motility and reactivity after injuries. Time lapse studies of astrocytes in acute slice and slice culture have shown that astrocyte processes act much like dendritic spines; they are frequently motile and contact active synapses $[3,55,57]$, the role of this feature implying the synaptic remodelling.

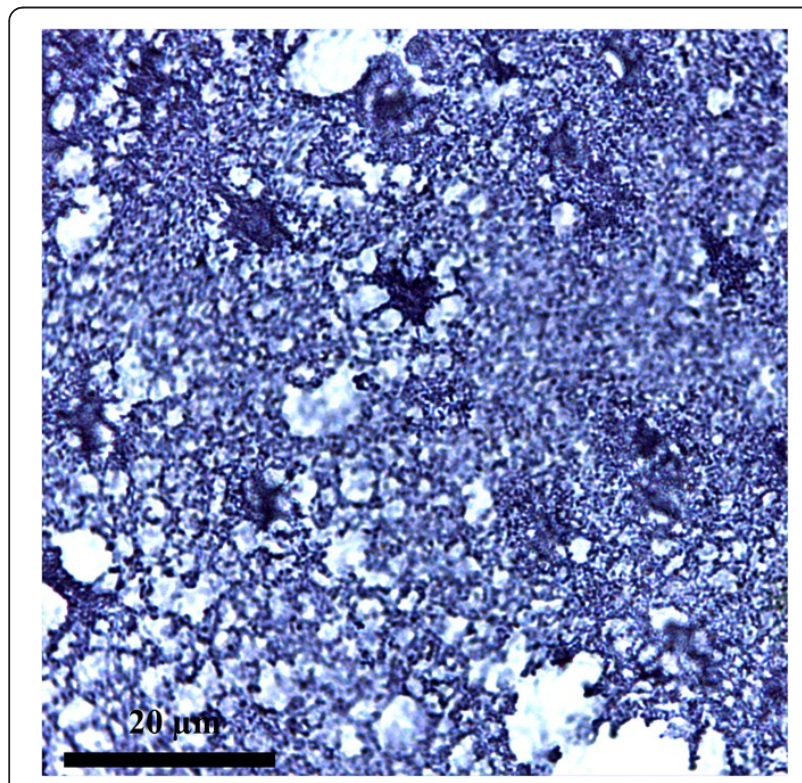

Figure 5 Protoplasmic astrocyte. Metallic impregnation Ramon Y Cajal Ob. 100 immersion. Human brain (personal collection).

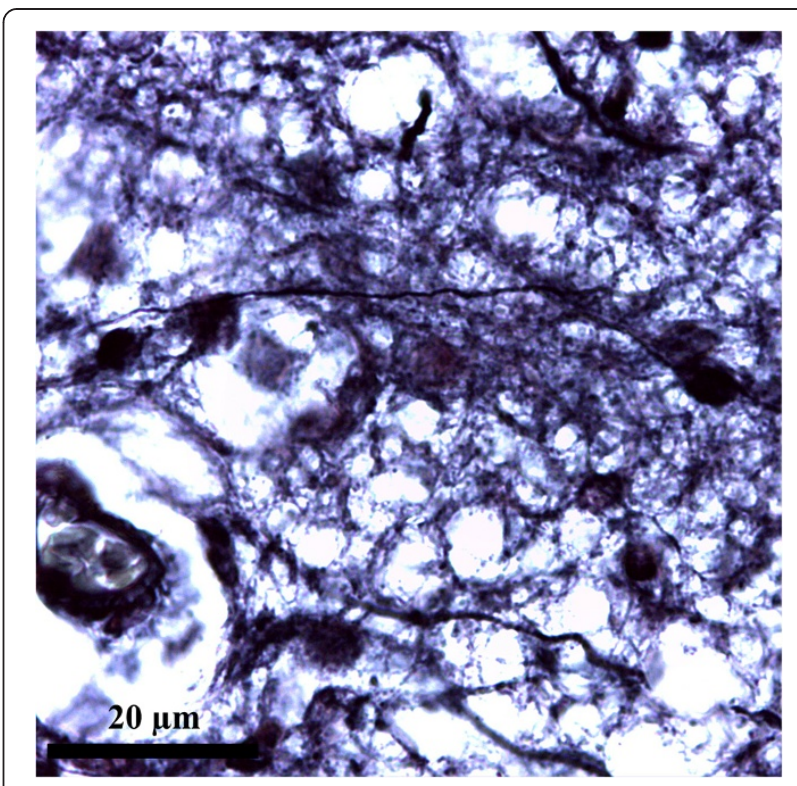

Figure 6 Fibrous astrocyte. Metallic impregnation Ramon Y Cajal Ob. 100 immersion. Human brain (personal collection).

\section{Reactive astrocytes}

Astrocytes become reactive notably after injuries, when the intermediate filament proteins (e.g. GFAP, vimentin, nestin) are upregulated, becoming larger and there is an alteration of the domain organization $[58,59]$.

The reactive morphological variants comprise two main categories: the individualised and the global reactive astrocytes. Individualized reactive astrocytes encompass several types: pilocytic astrocyte, gemistocytic astrocyte, type I and II Alzheimer astrocytes. The global reactive astrocytes are the characteristic feature of reactive astrogliosis (see Table 4) [60].

Reactive astrogliosis, a hallmark of all forms of CNS injuries, is the result of a multi-step process involving gradates changes in astrocytes.

Histopathological examinations of human brain in various neurological conditions have provided different degrees of reactive astrogliosis. According to Sofroniew et al., the following categories of reactive astrogliosis can be identified: mild to moderate astrogliosis, severe astrogliosis and the glial scar [60].

Mild to moderate astrogliosis is a manifestation of various disorders (systemic viral and bacterial infections, non-penetrating trauma) and also found in the distant areas surrounding the focal cerebral lesions [60]. The changes associated with mild to moderate astrogliosis are reversible if the triggering mechanism has resolved. In this type of injuries, subtle alterations occur in the expression of molecules implicated in the cellular activity: cell structure, energy metabolism, intracellular signaling, membrane transporters and pumps [60]. 
Table 4 Individualized reactive astrocytes variants

\begin{tabular}{|c|c|c|c|}
\hline $\begin{array}{l}\text { Individualized } \\
\text { reactive astrocytes } \\
\text { variants }\end{array}$ & Causes & Morphology & Particularities \\
\hline \multirow[t]{3}{*}{$\begin{array}{l}\text { Pilocytic astrocytes } \\
{[23,24]}\end{array}$} & $\begin{array}{l}\text { - In mild and moderate injuries } \\
\text { as individual form of reactive } \\
\text { astrocytes }\end{array}$ & $\begin{array}{l}\text { - Elongated, bipolar } \\
\text { cell body }\end{array}$ & \multirow[t]{3}{*}{$\begin{array}{l}\text { These cells contain the Rosenthal fibers (specific but inconstant } \\
\text { eosinophilic, cork-screw shaped elements), representing an } \\
\text { advanced stage of cellular degeneration in astrocytoma }\end{array}$} \\
\hline & \multirow[t]{2}{*}{ • Astrocytoma } & - Fusiform nuclei & \\
\hline & & $\begin{array}{l}\text { - Thin and long } \\
\text { hair-like GFAP } \\
\text { processes }\end{array}$ & \\
\hline \multirow[t]{4}{*}{$\begin{array}{l}\text { Gemistocytic } \\
\text { astrocytes }[23,24]\end{array}$} & $\begin{array}{l}\text { - In mild and moderate injuries } \\
\text { as individual form of reactive astrocytes }\end{array}$ & $\begin{array}{l}\text { - Large, dilatated, } \\
\text { oval cell body }\end{array}$ & \multirow{4}{*}{$\begin{array}{l}\text { The organelles are numerous and located in the central zone } \\
\text { of the cell body. The glial filaments are also numerous and } \\
\text { peripherally arranged, beneath the plasmalemma }\end{array}$} \\
\hline & \multirow[t]{3}{*}{$\begin{array}{l}\text { - In gemistocytic astrocytoma } \\
\text { as a characteristic feature of } \\
\text { this tumors [23] }\end{array}$} & $\begin{array}{l}\text { - Few thick } \\
\text { cytoplasmic } \\
\text { processes }\end{array}$ & \\
\hline & & $\begin{array}{l}\text { - Abundant, deeply } \\
\text { eosinophilic } \\
\text { cytoplasm }\end{array}$ & \\
\hline & & $\begin{array}{l}\text { - Polymorphic } \\
\text { nuclei, frequently } \\
\text { eccentrical. }\end{array}$ & \\
\hline \multirow[t]{2}{*}{$\begin{array}{l}\text { Alzheimer type I } \\
\text { astrocytes }[23,24]\end{array}$} & \multirow[t]{2}{*}{$\begin{array}{l}\text { - Progressive multifocal } \\
\text { leuco-encephalopathy }\end{array}$} & $\begin{array}{l}\text { - Enlarged cell } \\
\text { body }\end{array}$ & \\
\hline & & - Numerous nuclei & \\
\hline \multirow[t]{2}{*}{$\begin{array}{l}\text { Alzheimer type II } \\
\text { astrocytes }[23,24]\end{array}$} & $\begin{array}{l}\text { - Associated with high blood } \\
\text { ammonia in hepatic } \\
\text { encephalopathy }\end{array}$ & $\begin{array}{l}\text { - Enlarged cell } \\
\text { body }\end{array}$ & \multirow[t]{2}{*}{$\begin{array}{l}\text { Ammonia taken up by astrocytes is converted to osmotically } \\
\text { active glutamine, resulting in astrocytic swelling }\end{array}$} \\
\hline & - In Wilson disease & $\begin{array}{l}\text { - Vesicular nuclei } \\
\text { with one or more } \\
\text { nucleoli }\end{array}$ & \\
\hline
\end{tabular}

Table 5 Reactive astrogliosis

\begin{tabular}{|c|c|c|c|}
\hline \multirow{2}{*}{$\begin{array}{l}\text { Reactive } \\
\text { astrogliois }\end{array}$} & \multirow{2}{*}{$\begin{array}{l}\text { Changes in astrocytes } \\
\text { morphology }\end{array}$} & \multicolumn{2}{|l|}{ Changes in molecules expression } \\
\hline & & Upregulated molecules & Upregulated or downregulated molecules \\
\hline \multirow{6}{*}{$\begin{array}{l}\text { Mild to } \\
\text { moderate } \\
\text { astrogliosis }\end{array}$} & • Hypertrophy of cell body & $\begin{array}{l}\text { - Structural elements: GFAP, nestin, } \\
\text { vimentin }\end{array}$ & $\begin{array}{l}\text { - Inflammatory cell regulators: cytokines, growth factors, } \\
\text { glutathione }\end{array}$ \\
\hline & \multirow[t]{2}{*}{$\begin{array}{l}\text { - Astrocytes processes are are } \\
\text { numerous and thicker }\end{array}$} & \multirow{5}{*}{$\begin{array}{l}\text { - Transcriptional regulators: STAT3, } \\
\text { NFkB, Rheb-m TOR, cAMP, Olig2, } \\
\text { SOX9 [61-65]. }\end{array}$} & $\begin{array}{l}\text { - Transporters and pumps: AQP4 and } \mathrm{Na}^{+} / \mathrm{K}^{+} \text {transporters } \\
{[61,66-69]}\end{array}$ \\
\hline & & & - Glutamate transporter [70-73] \\
\hline & \multirow{3}{*}{$\begin{array}{l}\text { - The non-overlapping domains } \\
\text { of individual astrocytes are } \\
\text { preserved }\end{array}$} & & - Vascular regulators: PGE, NO [74,75] \\
\hline & & & • Energy provision: lactate [76] \\
\hline & & & - Molecules implicated in synapse formation and \\
\hline \multirow{5}{*}{$\begin{array}{l}\text { Severe } \\
\text { astrogliosis } \\
\text { and glial scar }\end{array}$} & $\begin{array}{l}\text { - Intense hypertrophy of cell } \\
\text { body }\end{array}$ & & - Remodeling: thrombospondin and Complement C1q $[77,78]$ \\
\hline & - Significant extension of processes & & $\begin{array}{l}\text { - Molecules implicated in oxidative stress and providing } \\
\text { protection from oxidative stress: NO, NOS, SOD, } \\
\text { Glutathione }[67,68,79]\end{array}$ \\
\hline & - Proliferation & & \\
\hline & $\begin{array}{l}\text { - Overlapping of individual } \\
\text { domains }\end{array}$ & & \\
\hline & $\begin{array}{l}\text { - Substantial reorganization of } \\
\text { tissue architecture [60] }\end{array}$ & & \\
\hline
\end{tabular}


Various functional categories of genes and molecules modulated by reactive astrocytes can be either upregulated or downregulated, depending on the trigger or the moment after the insult. As a result of these alterations, specific histopathological features can be identified in astrocytes (see Table 5).

Severe diffuse reactive astrogliosis is characterised by permanent, pronounced and long-lasting changes and it is found in the areas surrounding severe focal lesions or infections, as well as in neurodegeneration [60].

Compact scar formation occurs in most severe injuries, such as overt tissue damage (e.g. penetrating or contusive trauma), inflammation initiated by invasive infections or abscesses, neoplasm and chronic neurodegeneration. Reactive astrogliosis reaches its highest level of activation: astrocytes undergo intense proliferation, and their long, branched processes overlap (see Table 5) [60].

Any cell type in the CNS (e.g. neurons, all types of glial cells, endothelial cells and leucocytes) is potentially able to release the molecular mediators of astrogliosis [60]. Signaling pathways and molecules implicated in mediating specific aspects of reactive astrogliosis include: STAT3 (signal transducer and activator of transcription 3), NFKB (nuclear factor kappa B), cAMP (cyclic adenosine monophosphate), all these inducing upregulation of structural molecules (e.g. GFAP, vimentin, nestin) $[62,63,80]$; moreover, STAT3 induces astrocyte hypertrophy, scar formation and exerts anti-inflammatory effect [62]; NFkB exerts pro-inflammatory effect $[63,81]$; Olig2, Endothelin-1 induce astrocyte proliferation $[65,82]$.

The newly formed cells in the glial scar derive from different sources: mature astrocytes that re-enter the cell cycle, NG2 progenitors and ependymal cells progenitors.

Molecular mediators and triggers leading to proliferation include: cytokines and growth factors (e.g. IL (interleukin) 6, LIF (leukemia inhibitory factor), CNTF, IL1, IL10, TGF $\beta$ (transforming growth factor), TNF $\alpha$ (tumor necrosis factor), INF $\gamma$ (interferon), [63,69]), Toll-like receptor ligants [83], LPS (lipopolysaccharide), molecules of oxidative stress (e.g. NO (nitric oxide) and ROS (reactive oxygen species) [67]), modulators and neurotransmitters (e.g. noradrenalin and glutamate [84]), ischemia associated hypoxia and glucose deprivation [67], neurodegeneration associated amyloid- beta [85] and ATP (adenosine triphosphate) released by cell injury [86].

Reactive astrocytes interact with other cell types: fibromeningeal cells and NG-2 positive glia and are associated with a dense collagenous extracellular matrix to form complex glial scars $[60,62,87]$. The changes leading to scar formation persist even after the triggering factor has been removed $[61,62,88,89]$.

Recent evidence suggest that the glial scars might have a beneficial role, as they form narrow, dense and compact barriers; these barriers delimit the periphery of severe tissue damage, isolate the lesion, thus preventing inflammatory cells and infectious agents from spreading into the healthy parenchyma [90].

\section{Conclusions}

This part of the review is an insight into the morphology and biology of astrocytes, with an emphasis on the latest findings concerning the novel cell subtypes, the developmental lineages and their functions.

From the very first description of astrocytes in the $19^{\text {th }}$ century, these cells concept has been at a standstill until recently when it remarkably progressed.

The variety of glial precursors, their ability to display stem cells features and different adult astrocytes morphology certify that the astrocytic phenotype is influenced by both the local cytoarchitecture and the functional requirements in specific brain areas.

\section{Abbreviations}

AldhL1: Aldehyde dehydrogenase 1 family, member 11; AQP4: Aquaporin 4; ATP: Adenosine triphosphate; BBB: Blood-brain barrier; bFGF: Basic fibroblast growth factor; BLBP: Brain lipid basic protein; BMF: Bone Morphogenetic Proteins; CAMP: Cyclic adenosine monophosphate; CNS: Central nervous system; CNTF: Ciliary neurotrophic factor; Dlx2: Distal-less homeobox 2; ECM: Extracellular matrix; EGF: Epidermal growth factor; EAAT: Excitatory amino-acid transporters; FBS: Fetal bovine serum; FGF: Fibroblast growth factor; GLAST: Glutamate amino acid transporters; GLT: Glutamate transporters; GFAP: Glial fibrillary acidic protein; GFP: Green fluorescent protein; GRP: Glial-restricted precursors; HBB: Hemolymph-brain barrier; IL: Interleukin; INF: Interferon; Kir 4.1: Inwardly rectifying K + channels; LIF: Leukemia inhibitory factor; LPS: Lipopolysaccharide; NFKB: Nuclear factor kappa B; NO: Nitric oxide; NOS: Nitric oxide synthase; OLIG2: Oligodendrocyte transcription factor; PGE: Prostaglandin E; Rheb-m TOR: Ras homolog enriched in brain - mamalian target of rapamycin; ROS: Reactive oxygen species; SOD: Superoxide dismutase; SOX9: Transcription factor SOX9; STAT3: Signal transducer and activator of transcription 3; SGZ: Subgranular zone; SVZ: Subventricular zone; TGF: Transforming growth factor; Tnc: Tenascin C; TNF: Tumor necrosis factor; VZ: Ventricular zone.

\section{Competing interests}

The authors declare that they have no competing interests.

\section{Authors' contributions}

The images are part of the personal collection of the first author. Both authors contribute to the synthesis of the data from the actual scientific literature. All authors read and approved the final manuscript.

Received: 7 June 2013 Accepted: 5 August 2013

Published: 24 October 2013

\section{References}

1. Wang DD, Bordey A: The astrocyte odyssey. Prog Neurobio/ 2008, 86(4):342-367

2. Parpura $V$, Verkhratsky A: Neuroglia at the crossroads of homoeostasis, metabolism and signalling: evolution of the concept. ASN Neuro 2012, 4(4):201-205.

3. Oberheim NA, Goldman SA, Nedergaard M: Heterogeneity of astrocytic form and function. Methods Mol Biol 2012, 814:23-45.

4. Andriezen WL: The neuroglia elements in the human brain. Br Med J 1893, 2(1700):227-230.

5. Parpura V, Verkhratsky A: Astrocytes revisited: concise historic outlook on glutamate homeostasis and signaling. Croat Med J 2012, 53(6):518-528.

6. Kimelberg HK, Nedergaard M: Functions of astrocytes and their potential as therapeutic targets. Neurotherapeutics 2010, 7(4):338-353.

7. Bélanger M, Magistretti PJ: The role of astroglia in neuroprotection. Dialogues Clin Neurosci 2009, 11(3):281-295. 
8. Haas C, Neuhuber B, Yamagami T, Rao M, Fischer I: Phenotypic analysis of astrocytes derived from glial restricted precursors and their impact on axon regeneration. Exp Neurol 2012 Feb, 233(2):717-732.

9. Kang W, Hébert JM: Signaling pathways in reactive astrocytes, a genetic perspective. Mol Neurobiol 2011, 43(3):147-154.

10. Wiese $\mathrm{S}$, Karus M, Faissner A: Astrocytes as a source for extracellular matrix molecules and cytokines. Front Pharmacol 2012, 3:120.

11. Malatesta P, Hartfuss $E$, Götz M: Isolation of radial glial cells by fluorescent-activated cell sorting reveals a neuronal lineage. Development 2000, 127(24):5253-5263.

12. Noctor SC, Flint AC, Weissman TA, Dammerman RS, Kriegstein AR: Neurons derived from radial glial cells establish radial units in neocortex. Nature 2001, 409(6821):714-720

13. Liu Y, Wu Y, Lee JC, Xue H, Pevny LH, Kaprielian Z, Rao MS: Oligodendrocyte and astrocyte development in rodents: an in situ and immunohistological analysis during embryonic development. Glia 2002, 40(1):25-43.

14. Cai J, Chen Y, Cai WH, Hurlock EC, Wu H, Kernie SG, Parada LF, Lu QR: A crucial role for Olig2 in white matter astrocyte development. Development 2007, 134(10):1887-1999.

15. Liu Y, Rao MS: Glial progenitors in the CNS and possible lineage relationships among them. Biol Cell 2004, 96(4):279-290.

16. Schmechel DE, Rakic PA: Golgi study of radial glial cells in developing monkey telencephalon: morphogenesis and transformation into astrocytes. Anat Embryol (Berl) 1979, 156(2):115-152.

17. Gates MA, Thomas LB, Howard EM, Laywell ED, Sajin B, Faissner A, Götz B, Silver J, Steindler DA: Cell and molecular analysis of the developing and adult mouse subventricular zone of the cerebral hemispheres. J Comp Neurol 1995, 361(2):249-266.

18. Cameron HA, Woolley CS, McEwen BS, Gould E: Differentiation of newly born neurons and glia in the dentate gyrus of the adult rat. Neuroscience 1993, 56(2):337-344.

19. Doetsch F, Caillé I, Lim DA, García-Verdugo JM, Alvarez-Buylla A: Subventricular zone astrocytes are neural stem cells in the adult mammalian brain. Cell 1999, 97(6):703-716.

20. Seri B, García-Verdugo JM, McEwen BS, Alvarez-Buylla A: Astrocytes give rise to new neurons in the adult mammalian hippocampus. J Neurosci 2001, 21(18):7153-7160.

21. Altman J: Autoradiographic and histological studies of postnatal neurogenesis. IV. Cell proliferation and migration in the anterior forebrain, with special reference to persisting neurogenesis in the olfactory bulb. J Comp Neurol 1969, 137(4):433-457.

22. Luskin MB: Restricted proliferation and migration of postnatally generated neurons derived from the forebrain subventricular zone. Neuron 1993, 11(1):173-189.

23. Fuller GN, Burger PC: Central nervous system in Histology for pathologists. In Edited by Sternberg SS. New York: Raven Press; 1992:145-167.

24. Burger PC, Scheithauer BW: Tumors of the Central Nervous System-Armed Forces Institute of Pathology. In Atlas of Tumor Pathology. 3rd edition; 1993. Series Fascicle 10.

25. Liu X, Bolteus AJ, Balkin DM, Henschel O, Bordey A: GFAP-expressing cells in the postnatal subventricular zone display a unique glial phenotype intermediate between radial glia and astrocytes. Glia 2006, 54(5):394-410

26. Spassky N, Merkle FT, Flames N, Tramontin AD, García-Verdugo JM, Alvarez-Buylla A: Adult ependymal cells are postmitotic and are derived from radial glial cells during embryogenesis. J Neurosci 2005, 25(1):10-18

27. Buniatian $\mathrm{GH}$, Hartmann $\mathrm{HJ}$, Traub P, Wiesinger $H$, Albinus $M$, Nagel $W$, Shoeman R, Mecke D, Weser U: Glial fibrillary acidic protein-positive cells of the kidney are capable of raising a protective biochemical barrier similar to astrocytes: expression of metallothionein in podocytes. Anat Rec 2002, 267(4):296-306.

28. Davidoff MS, Middendorff R, Köfüncü E, Müller D, Jezek D, Holstein AF: Leydig cells of the human testis possess astrocyte and oligodendrocyte marker molecules. Acta Histochem 2002, 104(1):39-49.

29. Danielyan L, Tolstonog G, Traub P, Salvetter J, Gleiter CH, Reisig D, Gebhardt R, Buniatian GH: Colocalization of glial fibrillary acidic protein, metallothionein, and MHC II in human, rat, NOD/SCID, and nude mouse skin keratinocytes and fibroblasts. J Invest Dermatol 2007, 127(3):555-563.

30. Kasantikul V, Shuangshoti S: Positivity to glial fibrillary acidic protein in bone, cartilage, and chordoma. J Surg Oncol 1989, 41(1):22-26.
31. Baudier J, Glasser N, Gerard D: lons binding to S100 proteins. I. Calcium- and zinc-binding properties of bovine brain $\$ 100$ alpha alpha, S100a (alpha beta), and S100b (beta beta) protein: $\mathrm{Zn2}+$ regulates Ca2+ binding on S100b protein. J Biol Chem 1986, 261(18):8192-8203.

32. Schousboe A: Role of astrocytes in the maintenance and modulation of glutamatergic and GABAergic neurotransmission. Neurochem Res 2003, 28(2):347-352

33. Martinez-Hernandez A, Bell KP, Norenberg MD: Glutamine synthetase: glial localization in brain. Science 1977, 195(4284):1356-1358.

34. Cammer W: Glutamine synthetase in the central nervous system is not confined to astrocytes. J Neuroimmunol 1990, 26(2):173-178.

35. D'Amelio F, Eng LF, Gibbs MA: Glutamine synthetase immunoreactivity is present in oligodendroglia of various regions of the central nervous system. Glia 1990, 3(5):335-341.

36. Takumi T, Ishii T, Horio Y, Morishige K, Takahashi N, Yamada M, Yamashita T, Kiyama H, Sohmiya K, Nakanishi S: A novel ATP-dependent inward rectifier potassium channel expressed predominantly in glial cells. J Biol Chem 1995, 270(27):16339-16346

37. Higashi K, Fujita A, Inanobe A, Tanemoto M, Doi K, Kubo T, Kurachi Y: An inwardly rectifying $\mathrm{K}(+)$ channel, Kir4.1, Expressed in astrocytes surrounds synapses and blood vessels in brain. Am J Physiol Cell Physiol 2001, 281(3):C922-C931.

38. Nielsen S, Nagelhus EA, Amiry-Moghaddam M, Bourque C, Agre P, Ottersen OP: Specialized membrane domains for water transport in glial cells: high-resolution immunogold cytochemistry of aquaporin-4 in rat brain. J Neurosci 1997, 17(1):171-180.

39. Cahoy JD, Emery B, Kaushal A, Foo LC, Zamanian JL, Christopherson KS, Xing Y, Lubischer JL, Krieg PA, Krupenko SA, Thompson WJ, Barres BA: A transcriptome database for astrocytes, neurons, and oligodendrocytes: a new resource for understanding brain development and function. J Neurosci 2008, 28(1):264-278.

40. Emsley JG, Macklis JD: Astroglial heterogeneity closely reflects the neuronal-defined anatomy of the adult murine CNS. Neuron Glia Biol 2006, 2(3):175-186.

41. Nishiyama A, Yang Z, Butt A: Astrocytes and NG2-glia: what's in a name? J Anat 2005, 207(6):687-693.

42. Fiacco T, Casper K, Sweger E, Agulhon C, Taves S, Kurtzer-Minton S: Molecular approaches for studying astrocytes. In Astrocytes in (patho) physiology of the nervous system. Edited by Parpura V, Haydon PG. New York: Springer; 2009:383-405.

43. Bushong EA, Martone ME, Jones YZ, Ellisman MH: Protoplasmic astrocytes in CA1 stratum radiatum occupy separate anatomical domains. J Neurosci 2002, 22:183-192.

44. Ogata K, Kosaka T: Structural and quantitative analysis of astrocytes in the mouse hippocampus. Neuroscience 2002, 113:221-233.

45. Sofroniew MV, Vinters HV: Astrocytes: biology and pathology. Acta Neuropathol 2010, 119:7-35.

46. Oberheim NA, Takano T, Han X, He W, Lin JH, Wang F, Xu Q, Wyatt JD, Pilcher W, Ojemann JG, Ransom BR, Goldman SA, Nedergaard M: Uniquely hominid features of adult human astrocytes. J Neurosci 2009, 29:3276-3287

47. Retzius G: Die neuroglia des gehirns beim menschen und bei saeugethieren. Biol Untersuchungen 1894, 6:1-28.

48. Colombo JA, Reisin HD: Interlaminar astroglia of the cerebral cortex: a marker of the primate brain. Brain Res 2004, 1006:126-131.

49. Colombo JA, Yanez A, Puissant V, Lipina S: Long, interlaminar astroglial cell processes in the cortex of adult monkeys. J Neurosci Res 1995, 40:551-556.

50. Oberheim NA, Wang X, Goldman S, Nedergaard M: Astrocytic complexity distinguishes the human brain. Trends Neurosci 2006, 29:547-553.

51. Nishiyama A, Watanabe M, Yang Z, Bu J: Identity, distribution, and development of polydendrocytes: NG2-expressing glial cells. J Neurocytol 2002, 31:437-455.

52. Livet J, Weissman TA, Kang H, Draft RW, Lu J, Bennis RA, Sanes JR, Lichtman JW: Transgenic strategies for combinatorial expression of fluorescent proteins in the nervous system. Nature 2007, 450:56-62.

53. Halassa MM, Fellin T, Takano H, Dong JH, Haydon PG: Synaptic islands defined by the territory of a single astrocyte. J Neurosci 2007, 27:6473-6477

54. Oberheim NA, Tian GF, Han X, Peng W, Takano T, Ransom B, Nedergaard M: Loss of astrocytic domain organization in the epileptic brain. J Neurosci 2008, 28:3264-3276. 
55. Benediktsson AM, Schachtele SJ, Green SH, Dailey ME: Ballistic labeling and dynamic imaging of astrocytes in organotypic hippocampal slice cultures. J Neurosci Methods 2005, 141:41-53.

56. Hirrlinger J, Hulsmann S, Kirchhoff F: Astroglial processes show spontaneous motility at active synaptic terminals in situ. Eur J Neurosci 2004, 20:2235-2239.

57. Hewett JA: Determinants of regional and local diversity within the astroglial lineage of the normal central nervous system. J Neurochem 2009, 110:1717-1736.

58. Silver J, Miller JH: Regeneration beyond the glial scar. Nat Rev Neurosci 2004, 5:146-156.

59. Pekny M, Nilsson M: Astrocyte activation and reactive gliosis. Glia 2005 , 50:427-434.

60. Sofroniew MV: Molecular dissection of reactive astrogliosis and glial scar formation. Trends Neurosci 2009, 32(12):638-647.

61. Bush TG, Puvanachandra N, Horner CH, Polito A, Ostenfeld T, Svendsen CN Mucke L, Johnson MH, Sofroniew MV: Leukocyte infiltration, neuronal degeneration and neurite outgrowth after ablation of scar-forming, reactive astrocytes in adult transgenic mice. Neuron 1999, 23:297-308.

62. Herrmann JE, Imura T, Song B, Qi J, Ao Y, Nguyen TK, Korsak RA, Takeda K, Akira S, Sofroniew MV: STAT3 Is a critical regulator of astrogliosis and scar formation after spinal cord injury. J Neurosci 2008, 28:7231-7243.

63. Brambilla R, Bracchi-Ricard V, Hu WH, Frydel B, Bramwell A, Karmally S, Green EJ, Bethea JR: Inhibition of astroglial nuclear factor kappaB reduces inflammation and improves functional recovery after spinal cord injury. $J$ Exp Med 2005, 202:145-156.

64. Codeluppi S, Svensson Cl, Hefferan MP, Valencia F, Silldorff MD, Oshiro M, Marsala M, Pasquale EB: The rheb-mTOR pathway is upregulated in reactive astrocytes of the injured spinal cord. J Neurosci 2009, 29:1093-1104.

65. Chen Y, Miles DK, Hoang T, Shi J, Hurlock E, Kernie SG, Lu QR: The basic helix-loop-helix transcription factor olig2 is critical for reactive astrocyte proliferation after cortical injury. J Neurosci 2008, 28:10983-10989.

66. Eddleston M, Mucke L: Molecular profile of reactive astrocytes -implications for their role in neurological disease. Neuroscience 1993, 54:15-36.

67. Swanson RA, Ying W, Kauppinen TM: Astrocyte influences on ischemic neuronal death. Curr Mol Med 2004, 4:193-205.

68. Chen Y, Vartiainen NE, Ying W, Chan PH, Koistinaho J, Swanson RA: Astrocytes protect neurons from nitric oxide toxicity by a glutathione-dependent mechanism. J Neurochem 2001, 77:1601-1610.

69. John GR, Lee SC, Brosnan CF: Cytokines: powerful regulators of glial cell activation. Neuroscientist 2003, 9:10-22.

70. Zador Z, Stiver S, Wang V, Manley GT: Role of aquaporin-4 in cerebral edema and stroke. Handb Exp Pharmacol 2009, 190:159-170.

71. Simard M, Nedergaard M: The neurobiology of glia in the context of water and ion homeostasis. Neuroscience 2004, 129:877-896.

72. Maragakis NJ, Rothstein JD: Mechanisms of disease: astrocytes in neurodegenerative disease. Nat Clin Pract Neurol 2006, 2:679-689.

73. Rothstein JD, Dykes-Hoberg M, Pardo CA, Bristol LA, Jin L, Kund RW, Kanai Y, Hediger MA, Wang Y, Schielke JP, Welty DF: Knockout of glutamate transporters reveals a major role for astroglial transport in excitotoxicity and clearance of glutamate. Neuron 1996, 16:675-686.

74. ladecola C, Nedergaard M: Glial regulation of the cerebral microvasculature. Nat Neurosci 2007, 10:1369-1376.

75. Gordon GR, Mulligan SJ, MacVicar BA: Astrocyte control of the cerebrovasculature. Glia 2007, 55:1214-1221.

76. Pellerin L, Bouzier-Sore AK, Aubert A, Serres S, Merle M, Costalat R, Magistretti PJ: Activity-dependent regulation of energy metabolism by astrocytes: an update. Glia 2007, 55:1251-1262.

77. Christopherson KS, Ullian EM, Stokes CC, Mullowney CE, Hell JW, Agah A, Lawler J, Mosher DF, Bornstein P, Barres BA: Thrombospondins are astrocyte-secreted proteins that promote CNS synaptogenesis. Cell 2005, 120:421-433.

78. Stevens B, Allen NJ, Vazquez LE, Howell GR, Christopherson KS, Nouri N, Micheva KD, Mehalow AK, Huberman AD, Stafford B, Sher A, Litke AM, Lambris JD, Smith SJ, John SW, Barres BA: The classical complement cascade mediates CNS synapse elimination. Cell 2007, 131:1164-1178.

79. Hamby ME, Hewett JA, Hewett SJ: TGF-beta1 potentiates astrocytic nitric oxide production by expanding the population of astrocytes that express NOS-2. Glia 2006, 54:566-577.
80. Lee S, Park JY, Lee WH, Kim H, Park HC, Mori K, Suk K: Lipocalin-2 is an autocrine mediator of reactive astrocytosis. J Neurosci 2009, 29:234-249.

81. Gadea A, Schinelli S, Gallo V: Endothelin-1 regulates astrocyte proliferation and reactive gliosis via a JNK/c-Jun signaling pathway. J Neurosci 2008, 28:2394-2408.

82. Panenka W, Jijon H, Herx LM, Armstrong JN, Feighan D, Wei T, Yong WW, Ransohoff RM, MacVicar BA: P2X7-Like receptor activation in astrocytes increases Chemokine Monocyte chemoattractant protein-1 expression via mitogen-activated protein kinase. J Neurosci 2001, 21:7135-7142.

83. Farina C, Aloisi F, Meinl E: Astrocytes are active players in cerebral innate immunity. Trends Immunol 2007, 28:138-145.

84. Bekar LK, He W, Nedergaard M: Locus coeruleus alpha-adrenergic-mediated activation of cortical astrocytes in vivo. Cereb Cortex 2008, 18:2789-2795.

85. Simpson JE, Ince PG, Lace G, Forster G, Shaw PJ, Matthews F, Savva G, Brayne C, Wharton SB: Astrocyte phenotype in relation to Alzheimer-type pathology in the ageing brain. Neurobiol Aging 2008.

86. Neary JT, Kang Y, Willoughby KA, Ellis EF: Activation of extracellular signal-regulated kinase by stretch-induced injury in astrocytes involves extracellular ATP and P2 purinergic receptors. J Neurosci 2003, 23:2348-2356

87. De Keyser J, Mostert JP, Koch MW: Dysfunctional astrocytes as key players in the pathogenesis of central nervous system disorders. J Neurol Sci 2008, 267:3-16.

88. Gris $P$, Tighe A, Levin D, Sharma R, Brown A: Transcriptional regulation of scar gene expression in primary astrocytes. Glia 2007, 55:1145-1155.

89. Voskuhl RR, Peterson RS, Song B, Ao Y, Morales LB, Tiwari-Woodruff S, Sofroniew MV: Reactive astrocytes form scar-like barriers to leukocytes during adaptive immune inflammation of the central nervous system. J Neurosci 2009.

90. Hamby ME, Sofronew MV: Reactive astrocytes as therapeutic targets for CNS disorders. Neurotherapeutics 2010, 7(4):494-506.

doi:10.1186/2049-9256-1-18

Cite this article as: Şovrea and Boşca: Astrocytes reassessment - an evolving concept part one: embryology, biology, morphology and reactivity. Journal of Molecular Psychiatry 2013 1:18

\section{Submit your next manuscript to BioMed Central and take full advantage of:}

- Convenient online submission

- Thorough peer review

- No space constraints or color figure charges

- Immediate publication on acceptance

- Inclusion in PubMed, CAS, Scopus and Google Scholar

- Research which is freely available for redistribution 